\title{
Effects of Soil Chemical Properties and Seasonality on Mycorrhizal Status of Prickly Pear (Opuntia ficus-indica) Planted in Hot Arid Steppe Rangelands
} (Kesan daripada Sifat Kimia Tanah dan Keberkitaran Status Mikoriza Pir Deduri (Opuntia ficus-indica) yang Ditanam di Tanah Banjaran Panas Gersang Steppe)

\author{
S. NEFFAR*, A. BEDDIAR \& H. CHENCHOUNI
}

\begin{abstract}
Mycorrhizal fungi are an essential component to consider for better management of soil fertility, particularly in degraded rangelands of drylands. The present article presents a field survey of colonization and intensity of arbuscular mycorrhizal fungi (AMF) on prickly pear (Opuntia ficus-indica) roots from young (5 years old) and old (more than 20 years) plantations. The results observed were explained by seasonality and edaphic factors. Prickly pear roots showed a mycorrhizal frequency (F\%) up to $100 \%$ of colonization and a mycorrhizal intensity (M\%) that may exceed $70 \%$. According to ANOVAs, both $\mathrm{F} \%$ and $\mathrm{M} \%$ varied significantly between Prickly pear plantation ages, but only $\mathrm{M} \%$ between seasons. The Generalized linear model showed that edaphic factors have no effect on the variation of $\mathrm{F} \%$. However the statistical model showed that $\mathrm{M} \%$ were significantly influenced by active $\mathrm{CaCO}_{3}$, organic matter, carbon, nitrogen, phosphorus contents and C/N. Our findings highlight the importance of mycorrhization in rehabilitation programs of degraded rangelands by prickly pear plantations in semiarid and arid lands, particularly during early plant ages and under environmental abiotic stresses such as climate and soil type.
\end{abstract}

Keywords: Arbuscular mycorrhizal fungi; arid land reclamation; mycorrhization; Opuntia ficus-indica; soil factors; steppe degradation

\section{ABSTRAK}

Kulat mikoriza adalah komponen penting untuk dipertimbangkan dalam pengurusan kesuburan tanah yang lebih baik, terutamanya di tanah banjaran usang daripada tanah kering. Artikel ini membentangkan kaji selidik lapangan tentang penanaman daripada pengkolonian dan kemantapan kulat arbuskel mikoriza (AMF) akar pir deduri (Opuntia ficusindica) akar daripada kecil (5 tahun) dan tua (lebih 20 tahun). Keputusan ditunjukkan melalui keberkitaran dan faktor edafik. Akar pir deduri menunjukkan kekerapan mikoriza (F\%) sehingga 100\% pengkolonian dan keamatan mikoriza (M\%) yang boleh melebihi 70\%. Menurut ANOVAs, F\% dan M\% berubah dengan ketara antara usia ladang pir deduri, tetapi M\% hanya antara musim. Model linear menyeluruh menunjukkan bahawa faktor edafik tidak mempunyai kesan ke atas perubahan $\mathrm{F} \%$. Walau bagaimanapun model statistik menunjukkan bahawa $\mathrm{M} \%$ dipengaruhi secara signifikan oleh $\mathrm{CaCO}_{3}$, sebatian organik, karbon, nitrogen, kandungan fosforus dan C/N. Penemuan kami menekankan betapa pentingnya pemikorizaan dalam program pemulihan tanah banjaran usang di ladang pir deduri dalam tanah separa gersang dan gersang, terutamanya semasa awal musim penanaman dan di bawah tekanan persekitaran abiotik seperti iklim dan jenis tanah.

Kata kunci: Faktor tanah; kulat mikoriza arbuskula; Opuntia ficus-indica; pemikorizaan; steppe usang; tebus guna tanah gersang

\section{INTRODUCTION}

In arid and semi-arid lands, the degradation of plant communities (vegetation structure and species diversity) is concomitant with the degradation of physicochemical and biological properties of soil (Requena et al. 1996). However, the functioning and stability of terrestrial ecosystems are primarily depending on the composition and species diversity of vegetation cover (Tilman et al. 1996).

Mediterranean ecosystems are considered as very fragile systems since they are susceptible to various forms of degradation (Ferrol et al. 2004), which is correspondingly the case of the Algerian rangelands, where ecological studies focused on the degradation status of both soil and vegetation (Aïdoud et al. 2006). The latter is generally organized according to a mosaic of vegetation pockets (patchy distribution) composed from pioneer plant species. Moreover, due to the exposure of soils to wind and water erosions, genetic and functional diversity of soil microflora is intensely affected by these abiotic disturbances (Sanon 2009).

Mycorrhizal fungi are among the microbial components of soil that are susceptible to desertification and which diversity and abundance are significantly 
reduced under arid conditions (Bethlenfalvay \& Schüepp 1994). These microorganisms play an important role in both the relationship plant-soil and ecosystem dynamics (van der Heijden et al. 1998), because they enhance the ability of the plant to establish and cope with stress situations such as nutrient deficiency, droughts and other soil disturbances (Barea et al. 1997). Nowadays, it is also well demonstrated that mycorrhizal symbiosis influences the soil microbial functioning via its influence on some bacterial groups involved in major biogeochemical cycles (N, C and P) (FreyKlett et al. 2005). Consequently both soil characteristics (Jeffries et al. 2003) and plant community (Hartnett \& Wilson 1999) are affected by mycorrhization.

The Prickly pear (Opuntia ficus-indica L.) is an introduced plant particularly well adapted to environmental stress conditions occurring in arid and semi-arid areas (Neffar 2012; Neffar et al. 2014; Snyman 2006). It was planned to use it as a facilitator-plant or plant-nurse to promote the development of natural plant species and to force the regeneration process in the assumption that the rehabilitation of a degraded ecosystem is possible by shortening different phases of the gradual ecological succession.

Although new technologies are widely published through scientific literature, rehabilitation programs in Algeria do not value biological and symbiotic potentials of soils under native or non-native shrubs, such as the Prickly pear, as an alternative to improve plant physiological performances in disturbed habitats (Neffar 2012). On the one hand, the species is drought-resistant and it is a candidate for the improvement of marginal and infertile habitats (Neffar et al. 2011); on the other hand, little information was found about responses of the Prickly pear to arbuscular mycorrhizal fungi (AMF) (Cui \& Nobel 1992; North \& Nobel 1992; Zañudo-Hernández et al. 2010), although AMF represent the major part of soil microbial flora in various ecosystems (Bohrer et al. 2004; Brundrett et al. 1996). Moreover mycorrhizal symbioses play a key role in the rhizosphere in more than one way, namely mineral nutrition, water supply and disease and drought resistance (Boomsma \& Vyn 2008). However their role in arid ecosystems has received less attention, whereas their contribution to agricultural systems is well known in the literature (Carrillo-Garcia et al. 1999; Mekahlia et al. 2013).

While many studies have been undertaken on mycorrhizae worldwide, additionally to Algeria works (Beddiar 2003; Chafi \& Fortas 1999; Fraga-Beddiar \& Abda 2002; Fraga-Beddiar \& Le Tacon 1990; MeddadHamza et al. 2010; Mejstř́k \& Cudlín 1983); no study so far has been specifically focused on the mycorrhizal status of prickly pear, nor under arid conditions. Actually field investigation on the species remains completely unexplored at the North African scale.

Our assumptions revolve around the fact that soil factors influence the ecology of soil microflora (abundance, diversity and distribution) and mycorrhization is no exception to this rule (Hart et al. 2001). The status of this influence in terms of rehabilitation by vegetative plantation under arid climate conditions endorse the hypothesis that variation of soil physicochemical properties effect traits of soil microbes 'symbiotic fungi of mycorrhization' (Guissou et al. 1988), and thus soils proprieties would be improved accordingly when vegetation is established by rehabilitation 'planting' (Neffar et al. 2014). Therefore, we predict an increase in mycorrhization patterns, in particular mycorrhization intensity and diversity of fungal spores. However, since plants supply their nutritional requirements through mycorrhizae (Jeffries et al. 2003; Zhu et al. 2010), with in mind that these requirements varies according to plant age and seasonal conditions; we hypothesize that mycorrhization rates would significantly increase under unfavourable environmental conditions or when the energetic demand of the plant increases: low values of physicochemical soil parameters; hot-dry season and severe drought; early life stages of the symbiotic plant; and/or plant growing stage in spring.

The research questions of the current study are: What is the status of symbiotic mycorrhizae of introduced prickly pear variety amyclaea in semiarid and arid lands of North Africa; whether the age of prickly pear plantations and seasons affects the mycorrhization; and whether soil factors affect mycorrhization under arid conditions. Therefore the study aimed to estimate the frequency and intensity of mycorrhizal colonization in roots of prickly pear planted in an arid area of Eastern Algeria (M'zara Station, Southern Tebessa). Moreover the survey targets the understanding and explaining of the spatiotemporal variations of mycorrhization at rhizosphere of the shrub.

\section{MATERIALS AND METHODS}

\section{STUDY AREA}

M'zara site (3451'08.4'N and 08 $15^{\prime} 05.3$ 'E, $780 \mathrm{~m}$ asl) was chosen as a representative area of degraded arid Mediterranean ecosystems. Located in Tebessa province (Eastern Algeria), its climate is arid-type with very hot-dry summer and cold-dry winter. Average annual temperature is about $14.1^{\circ} \mathrm{C}$, with a minimum of $5.8^{\circ} \mathrm{C}$ in January and a maximum of $23.5^{\circ} \mathrm{C}$ in July. Average annual precipitation is $163 \mathrm{~mm}$ (Figure 1).

The sampled site represents an open degraded grassland steppe that is characterized by a sandy soil texture, skeletal structure and low rate of organic matter (Neffar et al. 2011). Desertification is the main factor involved in the natural process of degradation of these rangelands in Algeria; however climate change coupled with certain human activities such as the exploitation of natural lands for agriculture and overgrazing further accelerated the process (Aïdoud et al. 2006; Benabderrahmane \& Chenchouni 2010). According to Neffar et al. (2014), the vegetation is dominated by grasses with some very sparse patches of slow-growing shrubs dominated by Stipa tenacissima L., Lygeum spartum L., Arthtrophytum scoparium Pomel., Artemisia herba-alba Asso and Astragalus armatus Willd. 


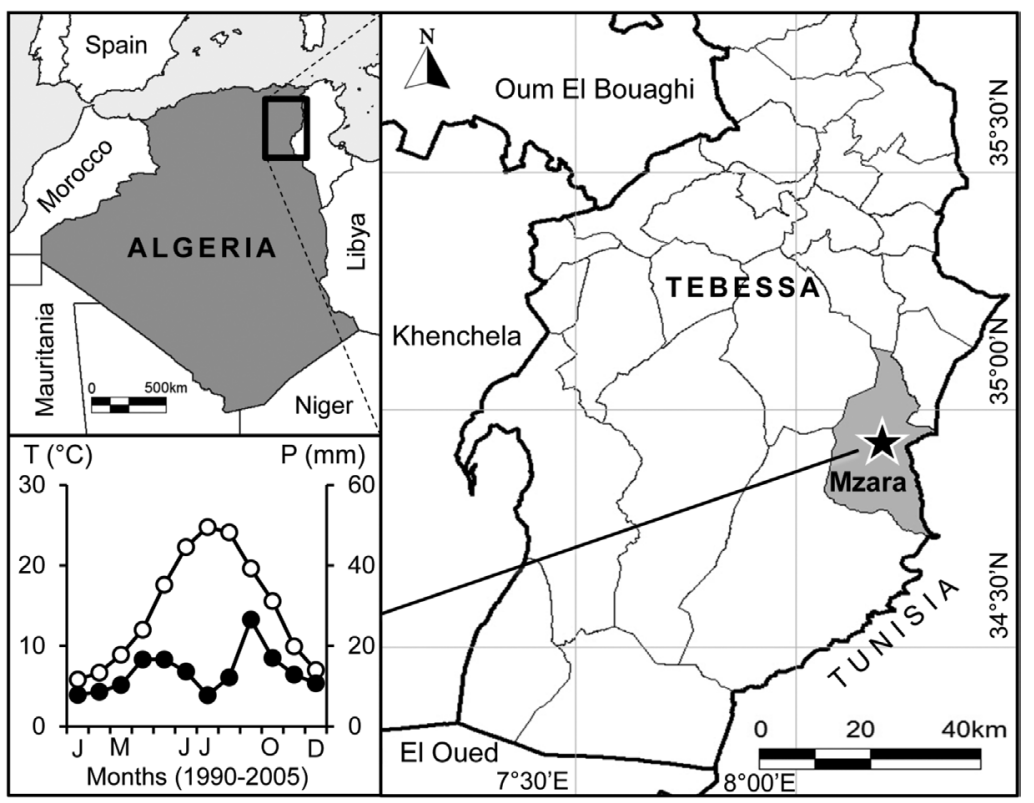

FIGURE 1. Location of the study area "M'zara" in Tebessa (East Algeria) with the climatic diagram of Gaussen and Bagnouls for the period 1990-2005. (empty circles represent mean temperatures and solid circles symbolize precipitation)

\section{SAMPLING OF SOIL AND ROOTS}

Soil samples were extracted in two types of plots planted with prickly pear: young plantations of at most 5 years and old plantations with more than 20 years. Three plots, of about 3 ha in size and similar topographic properties, were chosen as replicates for each plantation-type located in separate plantations. The sampled plots were selected close to each other to decrease spatial variations of edaphic and climatic factors. In each plot, 6-8 soil samples of about 1-2 kg per season were collected randomly under different prickly pear shrubs. Samples were carried out around the shrub trunk at a maximum depth of 10-20 cm. As the prickly pear has a superficial root system, the finest rootlets were collected at the same time including the sampled soil. Samples were put in bags and brought to the laboratory for processing. The sampling was carried out during four seasons from spring 2008 to winter 2009.

\section{SOIL ANALYSIS}

In the laboratory, the fine fraction $(\varnothing<2 \mathrm{~mm})$ of soil samples was retained for physical and chemical analysis according to standard methods and protocols (Neffar et al. 2014; Pansu \& Gautheyrou 2006). Electrical conductivity 'EC' and $\mathrm{pH}$ were measured in a $1 / 5(\mathrm{w} / \mathrm{v})$ aqueous solution. The levels of total calcium carbonate equivalent 'CCE' were determined by volumetric calcimetry. Whereas Drouineau's method was used to determine the amount of active calcium carbonate equivalent 'ACCE'. Organic carbon 'C' was analysed by dichromate oxidation method, then the rate of organic matter 'OM' was estimated by multiplying the percentage of carbon by 1.72. Total nitrogen ' $\mathrm{N}$ ' was estimated by Kjeldahl method. The Olsen method was used to determine available (= extractable) phosphorus 'AP' using a molybdate reaction for colorimetric detection. Total Phosphorus 'TP' was analysed using perchloric acid digestion method. Finally, particle size was determined by wet sieving method, once for each plantation type of prickly pear plantation. Then soil texture was derived by projecting particle fraction values of clay, silt and sand on the textural triangle according to USDA classification (Pansu \& Gautheyrou 2006).

\section{ROOT PREPARATION}

Separated from soil, the finest roots were washed with water, cut into fragments of $1 \mathrm{~cm}$ length then placed in test tube with $10 \%$ of $\mathrm{KOH}$ solution and kept during $24 \mathrm{~h}$. The test tube was kept at boiling point in water bath for $60 \mathrm{~min}$. The $\mathrm{KOH}$ solution was drained and the samples were washed with distilled water until the brown colour disappeared. Then Alkaline $\mathrm{H}_{2} \mathrm{O}_{2}$ was added to the samples for $10 \mathrm{~min}$ or until the roots were bleached. The samples were again rinsed to remove $\mathrm{H}_{2} \mathrm{O}_{2}$. These samples were treated with $2 \% \mathrm{HCl}$ for $30 \mathrm{~min}$ and stained in Chlorazol black $\mathrm{E}(0.1 \%)$ in the water bath at $90^{\circ} \mathrm{C}$ for $60 \mathrm{~min}$ (Phillips \& Hayman 1970). For each plot of plantation type of prickly pear per season, thirty root fragments were set up in glycerol on glass slides, with ten root fragments per glass slide. Samples were observed under a light microscope at magnifications $\times 10$ and $\times 40$.

\section{ESTIMATION OF MYCORRHIZATION}

Mycorrhization was assessed according to the method of Trouvelot et al. (1986) on the root fragments installed on glass slides previously prepared (containing 10 root 
fragments each). The following parameters were employed for the estimate of mycorrhization:

1. Mycorrhizal frequency $(\mathrm{F} \%)$ is rate of the number of endomycorrhized root fragments rounded to the ten root fragments of each slide.

2. Mycorrhizal intensity (M\%) represents the percentage of the mycorrhizal colonization developed in the endomycorrhized parts of the root system i.e. the ratio of colonized cells in endomycorrhized areas of the root.

\section{STATISTICAL ANALYSIS}

For each prickly pear plantation type, means and standard deviations of soil factors were given with interquartile rage and coefficient of variation. Soil parameters were tested for significant differences between prickly pear plantation types using One-way ANOVA.

Data of mycorrhization parameters $(F \%$ and $M \%)$ were processed by an analysis of variance (Two-way ANOVA) for the factors Age of prickly pear plantations, season and their interaction Age $\times$ Season. Means of the variables were compared using the Newman and Keuls test when a significant effect was observed. The multiple comparisons of means using the LSD were considered at probability level $p=0.05$.

To model the effects of edaphic factors on mycorrhization variables $(F \%$ and $M \%)$, generalized linear models (GLMs) were used with a Poisson distribution and log link (Fox 2008). The used data were seasonal replications of mycorrhization measured in plots of the two plantation types and the corresponding soil parameters. Additionally to the GLM summary of $F \%$ and $M \%$, null deviance $\left(D_{0}\right)$ and residual deviance $\left(D_{\mathrm{m}}\right)$ were given. All statistical tests and models were carried out using the Rcmdr package version 2.0-4 of R statistical software (R Development Core Team 2014).
RESULTS

PHYSICOCHEMICAL CHARACTERISTICS OF SOIL

Grain size data showed that all sampled soils had sandy texture, characterized by an alkaline $\mathrm{pH}$ (8.09 to 8.14) and a mean electrical conductivity ranged from 767 to $826 \mu \mathrm{S} \mathrm{cm}^{-1}$. Chemical analysis showed that the studied soils were generally poor of nutrients, especially $\mathrm{C}, \mathrm{N}$ and $\mathrm{AP}$; as well the $\mathrm{C} / \mathrm{N}$ ratio that had low values in both plantation types during all study seasons. The values of total $\mathrm{CaCO}_{3}$ were around $12 \%$ in young prickly pear plantations and $14 \%$ in old plantations. Overall soil analyses showed some heterogeneity of edaphic features between the two plantation ages. Actually ANOVA tests showed a significant variation in values of $\mathrm{EC}, \mathrm{pH}, \mathrm{ACCE}$, $\mathrm{N}$ and TP between the sampled plots (Table 1).

\section{TEMPORAL VARIATION OF MYCORRHIZATION}

The frequency of mycorrhization $(F \%)$ showed very slight variations between seasons and the age of prickly pear plantations. Its rates were very high during the four study seasons, but with a maximum (up to 100\%) in young prickly pear shrubs during fall and winter. The minimum value $(F \%=67 \%)$ was recorded during spring in old plantations (Figure 2(a)).

The ANOVA showed a significant effect $(p=0.005)$ for the factor 'age of plantation' of means of $F \%$. The effect of 'season' and the interactive effect of 'age $\times$ season' were not significant on variations of mycorrhization frequency (Table 2). The multiple comparisons of means using the LSD for the plantation type showed two homogeneous groups: The first consists of young plantations with an average of $F \%=94.44 \%$ and the second consists of old plantations with an average of $78.13 \%$.

TABLE 1. Physicochemical soil properties of sites planted with prickly pear in arid steppes of Eastern Algeria. Values were given in means ( \pm standard deviation: SD), interquartile range (IQR) and coefficient of variation $(\mathrm{CV})$ for each prickly pear plantation-type. The outputs of One-way ANOVA test are given as $F(d f$ between groups, $d f$ within groups) and $P$-value

\begin{tabular}{|c|c|c|c|c|c|c|c|c|}
\hline \multirow{2}{*}{ Soil traits } & \multicolumn{3}{|c|}{ Young plantations $(<5$ years $)$} & \multicolumn{3}{|c|}{ Old plantations (> 20 years) } & \multicolumn{2}{|c|}{ ANOVA } \\
\hline & Mean \pm SD & IQR & $\mathrm{CV}$ & Mean \pm SD & IQR & $\mathrm{CV}$ & $F_{(1,11)}$ & $P$ \\
\hline $\mathrm{EC}\left(\mu \mathrm{S} \mathrm{cm} \mathrm{cm}^{-1}\right)$ & $767.5 \pm 25.9$ & 43.0 & 0.03 & $826.2 \pm 82.0$ & 113 & 0.10 & 5.59 & 0.027 \\
\hline $\mathrm{pH}$ & $8.14 \pm 0.04$ & 0.06 & 0.004 & $8.10 \pm 0.03$ & 0.02 & 0.004 & 11.31 & 0.003 \\
\hline $\operatorname{CCE}(\%)$ & $12.05 \pm 3.73$ & 4.53 & 0.31 & $13.98 \pm 1.75$ & 2.05 & 0.13 & 2.65 & 0.118 \\
\hline $\operatorname{ACCE}(\%)$ & $4.82 \pm 2.37$ & 2.50 & 0.49 & $6.69 \pm 1.27$ & 1.00 & 0.19 & 5.85 & 0.024 \\
\hline OM (\%) & $0.60 \pm 0.43$ & 0.80 & 0.72 & $0.36 \pm 0.20$ & 0.31 & 0.55 & 2.94 & 0.100 \\
\hline $\mathrm{C}(\%)$ & $0.35 \pm 0.25$ & 0.46 & 0.72 & $0.21 \pm 0.12$ & 0.18 & 0.55 & 2.95 & 0.100 \\
\hline $\mathrm{N}(\%)$ & $0.07 \pm 0.02$ & 0.03 & 0.24 & $0.13 \pm 0.07$ & 0.11 & 0.53 & 9.54 & 0.005 \\
\hline $\mathrm{C} / \mathrm{N}$ & $6.52 \pm 6.12$ & 9.91 & 0.94 & $3.79 \pm 5.06$ & 3.33 & 1.33 & 1.41 & 0.248 \\
\hline $\mathrm{TP}(\%)$ & $69.96 \pm 40.55$ & 55.8 & 0.58 & $44.54 \pm 11.25$ & 20.4 & 0.25 & 4.38 & 0.048 \\
\hline $\mathrm{AP}(\mathrm{ppm})$ & $1.80 \pm 0.42$ & 0.67 & 0.23 & $1.44 \pm 0.63$ & 0.48 & 0.44 & 2.75 & 0.111 \\
\hline Clay (\%) & 13.52 & - & - & 8.14 & - & - & - & - \\
\hline Sand (\%) & 79.71 & - & - & 87.78 & - & - & - & - \\
\hline Silt (\%) & 6.76 & - & - & 4.07 & - & - & - & - \\
\hline
\end{tabular}



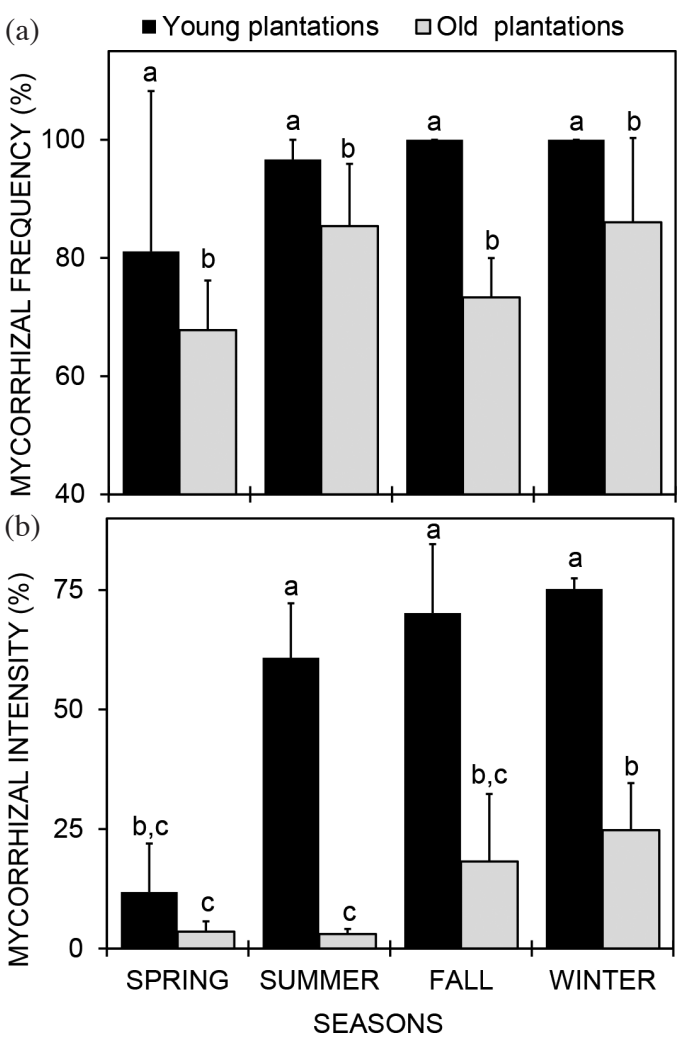

FIGURE 2. Seasonal variation of mycorrhizal frequency $(F \%)$ and intensity $(M \%)$ according to Prickly pear plantation ages.

Values with the same letters are significantly not different $(p<0.05)$ following the Newman and Keuls test

The intensity of mycorrhization $(M \%)$ varied significantly $(p<0.001)$ according to prickly pear plantation types, study seasons and the interaction effect of 'age $\times$ season' (Table 2). Indeed, values of $M \%$ were higher in young plots with percentages varying between 60 and $75 \%$ during summer and fall-winter, respectively; but its values decreased up to $11 \%$ in spring. In contrast, its rates were low in old plots during the four seasons, where $M \%$ ranged between 3 and 25\% (Figure 2(b)).

The colonization of prickly pear roots by AMF was manifested by the presence of mycelia (Figure 3(a), 3(b)), appressorium (Figure 3(c)), vesicles with different shapes and sizes (Figure 3(d)) and spores inside the sampled roots (Figure 3(e)), most likely of Glomus intraradices, morphological traits fits the description of Blaszkowski (2003). Over all, fungal mycelia colonized the roots in the form of non-partitioned filament that may be straight or tortuous, thin or large, in both inside and outside the root.

\section{EFFECTS OF EDAPHIC FACTORS ON MYCORRHIZATION}

The GLMs applied for mycorrhization parameters showed no significant linkage of the intercept of both models with $F \%$ and $M \%$ (Table 3). The first GLM showed that the proportion of endomycorrhized root fragments $(F \%)$ was not affected by any soil factors. However the second GLM, applied for mycorrhization intensity $(M \%)$, indicated a significant positive linkage (positive $Z$-value, $p<0.001$ ) of organic matter and available phosphorus with $M \%$. Likewise the latter parameter was negatively related to active $\mathrm{CaCO}_{3}$, carbon, nitrogen, $\mathrm{C} / \mathrm{N}$ ratio and total phosphorus content. Therefore it is mainly nutrient chemical elements of soil (OM, C, N, C/N, TP and AP), which have significant effects $(P<0.001)$ on $M \%$ (Table 3 ).

\section{DISCUSSIONS AND CONCLUSION}

Soil physicochemical analysis of the study sites showed sandy texture with low electrical conductivity values and slight contents of nutrients. These particular properties are common in soils of arid and semi-arid lands (Bradai et al. 2014; West et al. 1994). In general, mycorrhization parameters showed high levels during most seasons of the year, except spring, with lower values in old plantations compared with young plantations. This high mycorrhization could be a stimulus in soil stabilization since the aggregation of soil elements and particles is significantly supported by the growth of hyphae in the sand (Degens et al. 1999).

The literature characterizing mycorrhization worldwide showed that mycorrhizal results vary over time; for example Lingfei et al. (2005) reported that AMF colonization significantly fluctuates throughout the year

TABLE 2. Two-way analysis of variance (ANOVA) of mycorrhizal frequency $(F \%)$ and intensity $(M \%)$ according to prickly pear plantation age, season and their interaction

\begin{tabular}{clccccc}
\hline Parameter & \multicolumn{1}{c}{ Variation } & $S S$ & $D f$ & $M S$ & $F$ & $P$ \\
\hline \multirow{2}{*}{$F \%$} & Age of plantations & 1595.8 & 1 & 1595.8 & 10.83 & 0.005 \\
& Season & 1249.1 & 3 & 416.4 & 2.83 & 0.072 \\
& Age $\times$ Season & 220.6 & 3 & 73.5 & 0.50 & 0.688 \\
& Residuals & 2357.1 & 16 & 147.3 & & \\
& Total & 5422.6 & 23 & & & $<0.001$ \\
& Age of plantations & 10647.5 & 1 & 10647.5 & 114.54 & $<0.001$ \\
& Season & 6331.8 & 3 & 2110.6 & 22.71 & 8.37 \\
& Age $\times$ Season & 2334.6 & 3 & 778.2 & & 0.001 \\
& Residuals & 1487.3 & 16 & 93.0 & & \\
& Total & 20801.2 & 23 & & &
\end{tabular}




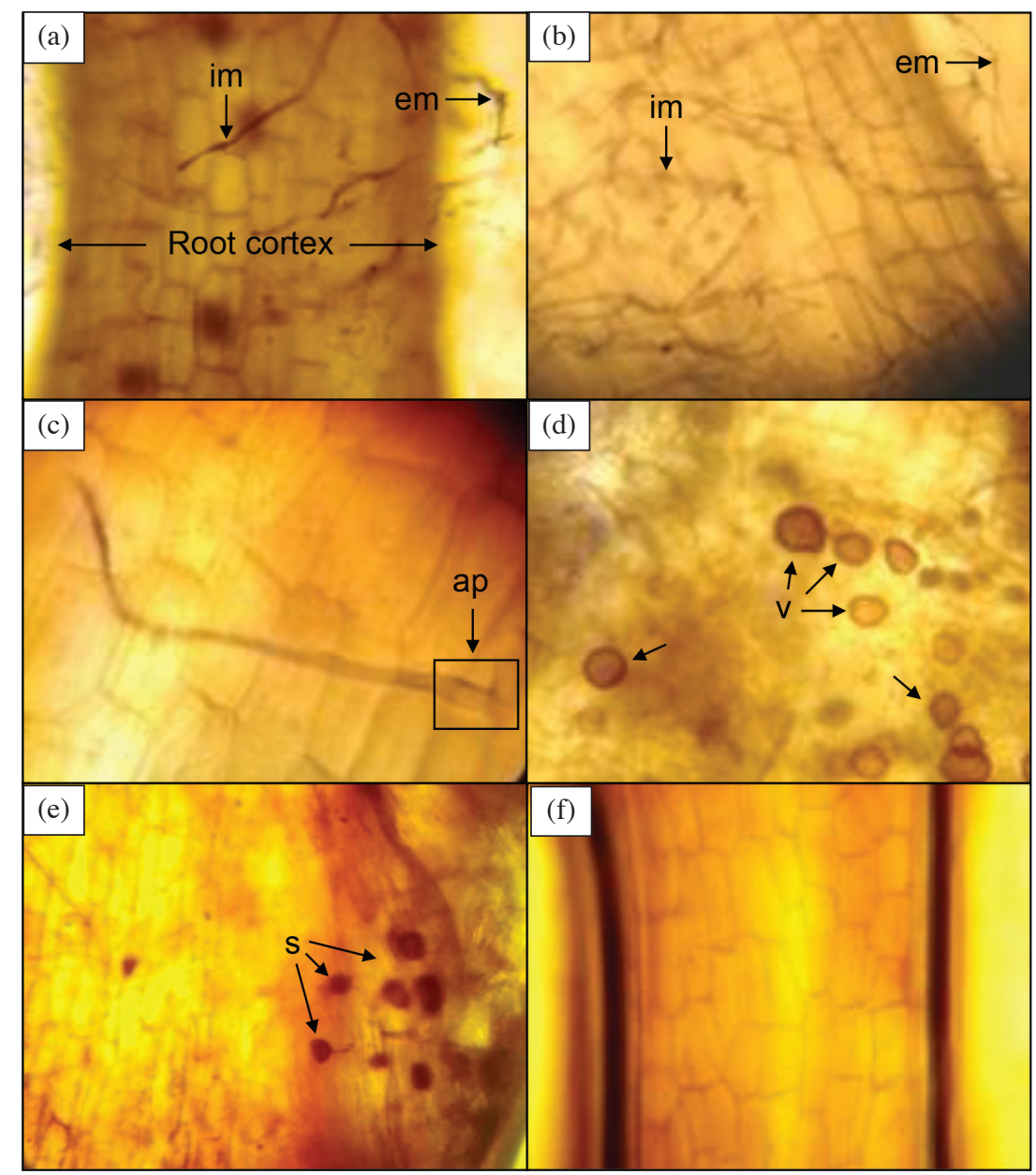

FIGURE 3. Mycorrhizal structures developed by arbuscular mycorrhizal fungi (AMF) in cleared and stained cortical cells of prickly pear roots. (a), (b): Intra-root mycelium (im) extra-root mycelium (em) ( $\times 80)$, (c) appressorium (ap) $(\times 320),(d)$ vesicles $(v)$ of different shapes $(\times 80),(e)$ spores $(s)(\times 80)$ and $(f)$ uncolonized root $(\times 80)$

where each plant species has different seasonal patterns of mycorrhization. In addition, the frequency and intensity of mycorrhization are dependent on several factors such as the age of the host species (Kessler et al. 2010), the physicochemical properties of soil (Escudero \& Mendoza 2005; Pande \& Tarafdar 2004), biogeographical location, seasonal and climatic variations (Bradai et al. 2015; Gui \& Nobel 1992; Mekahlia et al. 2013; Pimienta-Barrios et al. 2002), the number of propagules in the soil, and sporulation (Bohrer et al. 2004; Collier et al. 2003).

The relationships between the level of mycorrhizal colonization and physicochemical properties of soil were markedly variable (Smith \& Read 2008). Indeed, high levels of mycorrhizal infection were observed over a wide range of soil pH (Chmura \& Gucwa-Przepióra 2012), soil phosphates levels (Muthukumar \& Udaiyan 2002; Owens et al. 2012) and salinity concentrations (Abdel Latef \& Chaoxing 2011; Evelin et al. 2009). However, Nicolson (1960) found that colonization frequency in sand dune was not associated with variation of soil $\mathrm{pH}$ and calcium carbonate content, but mycorrhization has parallel variation as organic carbon content; which is in agreement with our findings. Moreover, Koske and Halvorson (1981) found no relationship between levels of soil inorganic nutrients and mycorrhizal colonisation, which is inconsistent with our results (i.e. GLM of $F \%$ in Table 3). However Wang et al. (1985) proved that the AMF behaviour was affected by soil $\mathrm{pH}$ and nutrient level. Indeed Dhillion and Friese (1992) demonstrated that plant species with high affinity for mycorrhization may have differential responses to AMF colonization due to nutrient availability and presence of soil microbes. AMF colonization may be differentially influenced due to a variety of factors (Owens et al. 2012). The significant effect of the main factors (season and plantation age) on the variation of mycorhization and the presence of a significance interactive effect (age $\times$ season) within the current study (Table 2) could be explained by the bioecological and ecophysiological characteristics of the host plant itself. Indeed, the Prickly pear, whose metabolism is type Crassulacean Acid Metabolism 'CAM' (Owen \& Griffiths 2014), is installed in a poor environment. Therefore it must maintain a high level of mycorrhization at all time to ensure the best physiological performance, in particular during seasons with harsh 
TABLE 3. GLM outputs (Poisson model with log link) testing the effects of edaphic factors on mycorrhization parameters ( $F \%$ and $M \%$ ) of the Prickly pear planted in arid rangelands of eastern Algeria

\begin{tabular}{|c|c|c|c|c|c|c|}
\hline Effect & Estimate & CI $2.5 \%$ & CI $97.5 \%$ & $S E$ & $Z$-value & $P$ \\
\hline$F \%$ & \multicolumn{6}{|c|}{$\left(D_{0}=66.69, d f=23 ; D_{\mathrm{m}}=47.19, d f=13\right)$} \\
\hline Intercept & 2.45 & -18.00 & 22.86 & 10.418 & 0.24 & 0.814 \\
\hline $\mathrm{EC}$ & 0.000 & -0.001 & 0.002 & 0.001 & 0.44 & 0.663 \\
\hline $\mathrm{pH}$ & 0.23 & -2.33 & 2.79 & 1.305 & 0.17 & 0.863 \\
\hline $\mathrm{CCE}$ & 0.05 & -0.02 & 0.13 & 0.040 & 1.34 & 0.181 \\
\hline ACCE & -0.06 & -0.16 & 0.03 & 0.049 & -1.32 & 0.188 \\
\hline $\mathrm{OM}$ & 4.71 & -32.36 & 41.78 & 18.907 & 0.25 & 0.803 \\
\hline $\mathrm{C}$ & -7.66 & -71.15 & 55.87 & 32.394 & -0.24 & 0.813 \\
\hline $\mathrm{N}$ & -2.69 & -5.49 & 0.10 & 1.427 & -1.89 & 0.059 \\
\hline $\mathrm{C} / \mathrm{N}$ & -0.02 & -0.05 & 0.01 & 0.013 & -1.48 & 0.139 \\
\hline $\mathrm{TP}$ & -0.004 & -0.01 & 0.00 & 0.002 & -1.80 & 0.072 \\
\hline $\mathrm{AP}$ & 0.06 & -0.10 & 0.22 & 0.083 & 0.74 & 0.463 \\
\hline$M \%$ & \multicolumn{6}{|c|}{$\left(D_{0}=679.41, d f=23 ; D_{\mathrm{m}}=358.80, d f=13\right)$} \\
\hline Intercept & 21.69 & -16.20 & 60.54 & 19.540 & 1.11 & 0.267 \\
\hline $\mathrm{EC}$ & 0.000 & -0.001 & 0.002 & 0.002 & 1.09 & 0.276 \\
\hline $\mathrm{pH}$ & -2.25 & -7.13 & 2.51 & 2.454 & -0.92 & 0.359 \\
\hline $\mathrm{CCE}$ & 0.09 & -0.08 & 0.26 & 0.086 & 1.02 & 0.309 \\
\hline ACCE & -0.23 & -0.43 & -0.03 & 0.101 & -2.25 & 0.025 \\
\hline $\mathrm{OM}$ & 145.70 & 85.30 & 207.26 & 31.090 & 4.69 & $<0.001$ \\
\hline $\mathrm{C}$ & -247.60 & -352.93 & -144.25 & 53.190 & -4.66 & $<0.001$ \\
\hline $\mathrm{N}$ & -18.16 & -23.83 & -12.78 & 2.812 & -6.46 & $<0.001$ \\
\hline $\mathrm{C} / \mathrm{N}$ & -0.15 & -0.20 & -0.09 & 0.028 & -5.28 & $<0.001$ \\
\hline $\mathrm{TP}$ & -0.004 & -0.02 & 0.00 & 0.005 & -2.30 & 0.022 \\
\hline $\mathrm{AP}$ & 1.07 & 0.75 & 1.40 & 0.164 & 6.51 & $<0.001$ \\
\hline
\end{tabular}

Note: $C I 2.5 \%, C I 95 \%$ : confidence intervals based on the profile likelihood, $S E$ : standard error, $D_{0}$ : null deviance, $D_{\mathrm{m}}$ : residual deviance, $d f:$ degree of freedom. For abbreviations of edaphic factors, see Table 1 .

climatic conditions like summer vs. spring (Mekahlia et al. 2013; Neffar et al. 2014). Moreover, during the early stages, the growth of plants is usually exponential (Fitter \& Hay 2012), so plants refer to mycorrhization in order to supplement their nutritional requirements (Biró et al. 2006). This statement is clearly observed through high mycorrhizal values of young plantations on the one hand and low values recorded in old plantation and during spring on the other hand (Figure 2).

Furthermore, the high rates of mycorrhization are probably attributed to: poor environmental conditions due low values of edaphic factors recorded in study plots; prickly pear variety planted in the region; and the aridity and drought that characterizes the area, which would have contributed to the increased level of root colonization. Actually it was demonstrated that colonization by AMF was higher in arid environments (Bohrer et al. 2004; Gui \& Nobel 1992; Mekahlia et al. 2013), and during dry-hot seasons, in particular (Mekahlia et al. 2013). Unlike annual plants, longevity of perennials meant they have need for mycorrhizae during the long periods of drought (Collier et al. 2003). In addition, the anatomy and morphology of roots may affect the intensity of colonization since the thick roots tend to have high rates of mycorrhization (Collier et al. 2003).

Regardless of the effects of edaphic factors on mycorrhizal status, the ANOVA showed a high significant variation of mycorrhizal colonization $(M \%)$ between the study seasons. Likewise these seasonal changes of mycorrhization patterns may also vary from one year to another depending on climatic conditions. Indeed, seasonal dynamics of AMF was demonstrated significant along different habitat types (Bohrer et al. 2004; Escudero \& Mendoza 2005), as well along a large gradient of climatic and hydrologic gradients, including temperate grasses and desert succulents (Escudero \& Mendoza 2005; Gui \& Nobel 1992; Mekahlia et al. 2013). This may be explained by seasonality differences in AMF biological activities, where we distinguish fungi that make sporulation in late spring and others in late summer (Bever et al. 2001; Caravaca et al. 2003).

We agree that this process is seasonal. It depends of both plants and soil factors which are very difficult to separate. Moreover, one of the more common justifications is to point out that is a result of a balance between the rate of growth of the roots within the soil and the fungus within the root. Probably, or may be surely in this case, the lower rate of colonization in spring for both populations is due to the higher growth rate of roots compared to that of fungus (García \& Mendoza 2008). This is consistent with the beginning of the growing season and the increases shown in rainfall and air temperate (Figure 1).

The genus Opuntia develops symbiotic associations with the AMF either in natural habitats or in glasshouse 
(Montiel \& Olivares 1997), but the overall colonization rate was low (Gui \& Nobel 1992; Pimienta-Barrios et al. 2002). However, the Prickly pear planted under hot arid conditions has high rates during different seasons (except spring), where colonization can reach $100 \%$ in winter. In addition, these mycorrhization rates are higher during young ages of the plant because at that stage, it has not yet grown enough in both aerial and radical systems to ensure its basic physiological performance independently of mycorrhizal means. Therefore mycorrhizae in the prickly pear planted in drylands are considered as compensable tool against various abiotic stresses.

Conducted with the aim of assessing the mycorrhizal status of the prickly pear planted in arid areas for the rehabilitation of the degraded soils, the present study revealed that the host plant was capable of developing an endomycorrhizal symbiosis with high mycorrhization rates throughout the year. The AMF present in the rhizosphere varied significantly according to soil nutrients (ACCE, OM, $\mathrm{C}, \mathrm{N}, \mathrm{C} / \mathrm{N}, \mathrm{TP}, \mathrm{AP})$, which have low values according to pedological analysis. These edaphic factors indicate the high degree of the degradation of the studied habitat. The rhizosphere likely contains AMF species that could detect high infectivity. In our context, a further study would be desirable to isolate and multiply AMF contained naturally in soils planted by Prickly pears, and test the effectiveness of the produced inoculum.

\section{REFERENCES}

Abdel Latef, A.A.H. \& Chaoxing, H. 2011. Effect of arbuscular mycorrhizal fungi on growth, mineral nutrition, antioxidant enzymes activity and fruit yield of tomato grown under salinity stress. Sci.Hortic. 127(3): 228-233.

Aïdoud, A., Le Floc'h, E. \& Le Houérou, H.N. 2006. Les steppes arides du nord de l'Afrique. Sécheresse 17(1): 19-30.

Barea, J.M., Azcon-Aguilar, C. \& Azcon, R. 1997. Interactions between mycorrhizal fungi and rhizosphere micro-organisms within the context of sustainable soil-plant systems. In Multitrophic Interactions in Terrestrial Systems, edited by Gange, A.C. \& Brown, V.K. Cambridge: Blackwell Science. pp. 65-77.

Beddiar, A. 2003. Les symbioses racinaires chez les principales essences forestières spontanées ou introduites dans le NordEst algérien (Etude particulière de la symbiose quadripartite chez l'Aulne glutineux). PhD Thesis, Annaba University, Algeria (unpublished).

Benabderrahmane, M.C. \& Chenchouni, H. 2010. Assessing environmental sensitivity areas to desertification in eastern Algeria using Mediterranean desertification and land use "MEDALUS" model. Int. J. Sust. Water Environ. Syst. 1(1): 5-10.

Bethlenfalvay, G.J. \& Schuëpp, H. 1994. Arbuscular mycorrhizas and agrosystem stability. In Impact of Arbuscular Mycorrhizas on Sustainable Agriculture and Natural Ecosystems, edited by Gianinazzi, S. \& Schuëp, H. Basel: Birkhaüser Verlag. pp. 171-313.

Bever, J., Schultz, P., Pringle, A. \& Morton, J. 2001. Arbuscular mycorrhizal fungi: More diverse than meets the eye, and the ecological tale of why. BioScience 51(11): 923-932.
Biró, B., Köves-Péchy, K., Tsimilli-Michael, M. \& Strasser, R.J. 2006. Role of beneficial microsymbionts on the plant performance and plant fitness. In Microbial Activity in the Rhizosphere (vol.7), edited by Mukerji,K.G., Manoharachary, C. \& Singh, J. Berlin, Heidelberg: Springer. pp. 265-296.

Błaszkowski, J. 2003. Glomus intraradices In Arbuscular Mycorrhizal Fungi (Glomeromycota), Endogone, and Complexipes Species deposited in the Department of Plant Pathology, University of Agriculture in Szczecin, Poland. Available at: www.agro.ar.szczecin.pl/ jblaszkowski/ Glomus\%20intraradices.html.

Bohrer, K., Friese, C. \& Amon, J. 2004. Seasonal dynamics of arbuscular mycorrhizal fungi in differing wetland habitats. Mycorrhiza 14(5): 329-337.

Boomsma, C.\& Vyn, T. 2008. Maize drought tolerance: Potential improvements through arbuscular mycorrhizal symbiosis. Field Crop Res. 108(1): 14-31.

Bradai, L., Bissati, S. \& Chenchouni, H. 2014. Desert truffles of the North Algerian Sahara: Diversity and bioecology. Emir. J. Food Agric. 26(5): 425-435.

Bradai,L., Bissati, S., Chenchouni, H. \& Amrani, K. 2015. Effects of climate on the productivity of desert truffles beneath hyperarid conditions. Int. J. Biometeorol. 59 doi: 10.1007/s00484014-0891-8 (In Press).

Brundrett, M.C., Ashwath, N.\& Jasper, D.A. 1996. Mycorrhizae in the Kakadu region of tropical Australia. Part II. Propagules of mycorrhizal fungi in disturbed habitats. Plant and Soil 184(1): 173-184.

Caravaca, F., Figueroa, D., Azcon-Aguilar, C., Barea, J.M. \& Roldan, A. 2003. Medium-term effects of mycorrhizal inoculation and composted municipal waste addition on the establishment of two Mediterranean shrub species under semiarid field conditions. Agr. Ecosyst. Environ. 97(1): 95-105.

Carrillo-Garcia, Á., La Luz, D., León, J.L., Bashan, Y. \& Bethlenfalvay, G.J. 1999. Nurse plants, mycorrhizae and plant establishment in a disturbed area of the Sonoran Desert. Restor. Ecol. 7(4): 321-335.

Chafi, M.E. \& Fortas, Z. 1999. Les mycorhizes des plantes des zones arides algériennes. Bois Forêts Trop. 262: 77-79.

Chmura, D. \& Gucwa-Przepióra, E. 2012. Interactions between arbuscular mycorrhiza and the growth of the invasive alien annual Impatiens parviflora DC: A study of forest type and soil properties in nature reserves (S Poland). Appl. Soil Ecol. 62(1): 71-80.

Collier, S., Yarnes, C. \& Peter Herman, R. 2003. Mycorrhizal dependency of Chihuahuan Desert plants is influenced by life history strategy and root morphology. J. Arid Environ. 55: 223-229.

Cui, M. \& Nobel, P.S. 1992. Nutrient status, water uptake and gas exchange for three desert succulents infected with mycorrhizal fungi. New Phytol. 122(4): 643-649.

Degens, B.P., Sparling, G.P. \& Abbott, L.K. 1999. Increasing the length of hyphae in a sandy soil increases the amount of water-stable aggregates. Appl. Soil Ecol. 3(2): 149-159.

Dhillion, S.S. \& Friese, C.F. 1992. The occurrence of mycorrhizas in prairies: Application to ecological restoration. In Proceedings of the $13^{\text {th }}$ North American Prairie Conference: Spirit of the Land, our Prairie Legacy, edited by Wickett, R.G., Lewis, P.D., Woodliffe, A. \& Pratt, P. Canada: University of Windsor. pp. 103-114.

Escudero, V. \& Mendoza, R. 2005. Seasonal variation of arbuscular mycorrhizal fungi in temperate grasslands along a wide hydrologic gradient. Mycorrhiza 15(4): 291-299. 
Evelin, H., Kapoor, R. \& Giri, B. 2009. Arbuscular mycorrhizal fungi in alleviation of salt stress: A review. Ann. Bot. 104(7): 1263-1280.

Ferrol, N., Calvente, R., Cano, C., Barea, T.M. \& Azcon-Aguilar, C. 2004. Analysing arbuscular mycorrhizal fungal diversity in shrub-associated resource islands from a desertification threatened semiarid Mediterranean ecosystem. Appl. Soil Ecol. 25(2): 123-133.

Fitter, A.H. \& Hay, R.K. 2012. Environmental Physiology of Plants. 3rd edition. New York: Academic Press.

Fox, J. 2008. Generalized linear models. In Applied Regression Analysis and Generalized Linear Models. 2nd ed., Chapter 15, edited by Fox, J. SAGE Publications. pp. 379-424.

Fraga-Beddiar, A. \& Abda, S. 2002. Statut mycorhizien du chêne liège (Quercus suber L.) et dynamique de la symbiose au cours des saisons. Synthèse 11: 108-114.

Fraga-Beddiar, A. \& Le Tacon, F. 1990. Interactions between a V.A. mycorrhizal fungus and Frankia associated with alder (Alnus glutinosa L. Gaertn.). Symbiosis 9(1-3): 247-258.

Frey-Klett, P., Chavatte, M., Clausse, M.L., Courrier, S., Roux, C.L., Raaijmakers, J. \& Garbaye, J., 2005. Ectomycorrhizal symbiosis affects functional diversity of rhizosphere fluorescent pseudomonads. New Phytol. 165(1): 317-328.

García, I. \& Mendoza, R.E. 2008. Relationships among soil properties, plant nutrition and arbuscular mycorrhizal fungiplant symbioses in a temperate grassland along hydrologic, saline and sodic gradients. FEMS Microbiol. Ecol. 63(3): 359-371.

Gui, M. \& Nobel, P.S. 1992. Nutrient status, water uptake and gas exchange for three desert succulents infected with mycorrhizal fungi. New Phytol. 122(4): 643-649.

Guissou, T., Ba, A.M., Ouadba, J.M., Guinko, S. \& Duponnois, R. 1988. Responses of Parkia biglobosa (Jacq.) Benth, Tamarindus indica L. and Zizyphus mauritiana Lam. to arbuscular mycorrhizal fungi in a phosphorus-deficient sandy soil. Biol. Fert. Soils 26(3): 194-198.

Hart, M.M., Reader, R.J. \& Klironomos, J.N. 2001. Life-history strategies of arbuscular mycorrhizal fungi in relation to their successional dynamics. Mycologia 93(6): 1186-1194.

Hartnett, D.C. \& Wilson, G.W. 1999. Mycorrhizae influence plant community structure and diversity in tallgrass prairie. Ecology 80(4): 1187-1195.

Jeffries, P., Gianinazzi, S., Perotto, S., Turnau, K. \& Barea, J.M. 2003. The contribution of arbuscular mycorrhizal fungi in sustainable maintenance of plant health and soil fertility. Biol. Fert. Soils 37(1): 1-16.

Kessler, M., Jonas, R., Strasberg, D. \& Lehnert, M. 2010. Mycorrhizal colonizations of ferns and lycophytes on the island of La Réunion in relation to nutrient availability. Basic Appl. Ecol. 11(4): 329-336.

Koske, R.E. \& Halvorson, W.L. 1981. Ecological studies of vesicular-arbuscular mycorrhizae in a barrier sand dune. Can . J. Bot. 59(8): 1413-1422.

Lingfei, L., Anna, Y. \& Zhiwei, Z. 2005. Seasonality of arbuscular mycorrhizal symbiosis and dark septate endophytes in a grassland site in southwest China. FEMS Microbiol. Ecol. 54(3): 367-373.

Meddad-Hamza, A., Beddiar, A., Golotte, A., Lemoine, M.C., Kuszala, C. \& Gianinazzi, S. 2010. Arbuscular mycorrhizal fungi improve the growth of olive trees and their resistance to transplantation stress. Afr. J. Biotech. 9(8): 1159-1167.

Mejstřík, V.K. \& Cudlín, P. 1983. Mycorrhiza in some plant desert species in Algeria. Plant Soil 71(1-3): 363-366.
Mekahlia,M.N.,Beddiar,A. \& Chenchouni,H. 2013. Mycorrhizal dependency in the olive tree (Olea europaea) across a xeric climatic gradient. Adv. Environ. Biol. 7(9): 2166-2174.

Montiel, S.D. \& Olivares, O.J. 1997. Presencia de la micorriza vesõculo-arbuscular en cuatro cultivares de nopal (Opuntia spp.) en Hichapan, Hidalgo. In Conocimiento y Aprovechamiento del Nopal, edited by Vazquez-Alvarado, R.E., Galle-Gos-Vazquez, C., Trevin Hernandez, N. \& Dõaz-Torres, Y. Memorias del VII Congreso Nacional y V Internacional. Fac. de Agronomõa, UANL, Monterrey, N.L. Mexico.

Muthukumar, T. \& Udaiyan, K. 2002. Seasonality of vesiculararbuscular mycorrhizae in sedges in a semi-arid tropical grassland. Acta Oecologica 23(5): 337-347.

Neffar, S. 2012. Étude de l'effet de l'âge des plantations de figuier de Barbarie (Opuntia ficus-indica L. Miller) sur la variation des ressources naturelles (sol et végétation) des steppes algériennes de l'Est. Cas de Souk Ahras et Tébessa. PhD Thesis, Univ. Annaba, Algeria (unpublished).

Neffar, S., Beddiar, A., Redjel, N. \& Boulkheloua, J. 2011 . Effets de l'âge des plantations de figuier de Barbarie (Opuntia ficus indica $\mathrm{f}$. inermis) sur les propriétés du sol et la végétation à Tébessa (zone semi-aride de l'est algérien). Ecologia Mediterranea 37(1): 5-15.

Neffar, S., Chenchouni, H., Beddiar, A. \& Redjel, N. 2014. Rehabilitation of degraded rangeland in drylands by Prickly pear (Opuntia ficus-indica L.) plantations: Effect on soil and spontaneous vegetation. Ecol. Balkanica 5(2): 63-76.

Nicolson, T.H. 1960. Mycorrhiza in the Gramineae. II. Development in different habitats, particularly sand dunes. Trans. Br. Mycol. Soc. 43(1): 132-145.

North, G.B. \& Nobel, P.S. 1992. Drought-induced changes in hydraulic conductivity and structure in roots of Ferocactus acanthodes and Opuntia ficus-indica. New Phytol. 120(1): 9-19.

Owen, N.A. \& Griffiths, H. 2014. Marginal land bioethanol yield potential of four crassulacean acid metabolism candidates (Agave fourcroydes, Agave salmiana, Agave tequilana and Opuntia ficus-indica) in Australia. GCB Bioenergy 6(6): 687-703.

Owens, H., LaFantasie, J. \& Adler, P. 2012. Mycorrhization rates of two grasses following alterations in moisture inputs in a southern mixed grass prairie. Appl. Soil Ecol. 60(1): 56-60.

Pande, M. \& Tarafdar, J.C. 2004 . Arbuscular mycorrhizal fungal diversity in neem-based agroforestry systems in Rajasthan. Appl. Soil Ecol. 26(3): 233-241.

Pansu, M. \& Gautheyrou, J. 2006. Handbook of Soil Analysis: Mineralogical, Organic and Inorganic Methods. Heidelberg: Springer-Verlag Berlin.

Phillips, J.M. \& Hayman, D.S. 1970. Improved procedures for clearing roots and staining parasitic and vesicular-arbuscular mycorrhizal fungi for rapid assessment of infection. Trans. Br. Mycol. Soc. 55(1): 159-161.

Pimienta-Barrios, E., Pimienta-Barrios, E., Salas-Galvan, M., Zanudo-Hernandez, J. \& Nobel, P. 2002. Growth and reproductive characteristics of the columnar cactus Stenocereus queretaroensis and their relationships with environmental factors and colonization by arbuscular mycorrhizae. Tree Physiol. 22(9): 667-674.

R Development Core Team. 2014. R: A Language and Environment for Statistical Computing. R Foundation for Statistical Computing, Vienna, Austria. Available at: http:// www.R-project.org/. 
Requena, N., Jeffries, P. \& Barea, J.M. 1996. Assessment of natural mycorrhizal potential in a desertified semiarid ecosystem. Appl. Environ. Microbiol. 62(3): 842-847.

Sanon, A. 2009. Le concept de niche écologique associé à la coexistence des espèces végétales: Mise en évidence du rôle de la symbiose mycorhizienne et de sa microflore associée dans la structuration de la strate herbacée en milieu tropical. $\mathrm{PhD}$ Thesis, University of Nancy (unpublished).

Smith, S.E. \& Read, D.J. 2008. Mycorrhizal Symbiosis. New York: Academic Press.

Snyman, H.A. 2006. A greenhouse study of root dynamics of cactus pears, Opuntia ficus-indica and O. robusta. J. Arid Environ. 65(4): 529-542.

Tilman, D., Wedin, D. \& Knops, J. 1996. Productivity and sustainability influenced by biodiversity in grassland ecosystems. Nature 379(6567): 718-720.

Trouvelot, A., Kouche, J. \& Gianinazzi-Pearson, V. 1986. Mesure du taux de mycorhization VA d'un système radiculaire: Recherche de méthodes d'estimation ayant une signification fonctionnelle. In: Les mycorhizes: Physiologie et Génétiques. Proceedings of 1st European Conference on Mycorrhizae. INRA, Dijon, Paris. pp. 217-221.

van der Heijden, M.G.A., Boller, T., Wiemken, A. \& Sanders, I.R. 1998. Different arbuscular mycorrhizal fungal species are potential determinants of plant community structure. Ecology 79(6): 2082-2091

Wang, G.M., Stribley, D.P., Tinker, P.G. \& Walker, C. 1985. Soil $\mathrm{pH}$ and vesicular-arbuscular mycorrhizae, In Ecological Interactions in Soil, edited by Fitter, A.H. Oxford: Blackwell Publication. pp. 219-224.

West, N.E., Stark, J.M., Johnson, D.W., Abrams, M.M., Wight, J.R., Heggem, D. \& Peck, S. 1994. Effects of climatic change on the edaphic features of arid and semi-arid lands of western North-America. Arid Soil Res. Rehabil. 8(4): 307-351.
Zañudo-Hernández, J., González del Castillo Aranda, E., Ramírez-Hernández, B.C., Pimienta-Barrios, E., CastilloCruz, I. \& Pimienta-Barrios, E. 2010. Ecophysiological responses of Opuntia to water stress under various semi-arid environments. J. Prof. Ass. Cactus Dev. 12: 20-36.

Zhu, X.C., Song, F.B. \& Xu, H.W. 2010. Arbuscular mycorrhizae improves low temperature stress in maize via alterations in host water status and photosynthesis. Plant Soil 331(1-2): 129-137.

Souad Neffar* \& Haroun Chenchouni

Department of Natural and Life Sciences

Faculty of Exact Sciences and Natural and Life Sciences University of Tebessa

12002 Tebessa

Algeria

Arifa Beddiar

Department of Biology

Faculty of Natural and Life Science

University of Badji Mokhtar

23000 Annaba

Algeria

*Corresponding author; email: neffarsouad@gmail.com

Received: 5 September 2014

Accepted: 13 January 2015 